\title{
Estimating genotype-environment interactions for internal fruit quality traits in cherry tomatoes
}

\section{Estimación de la interacción genotipo-ambiente de caracteres de calidad interna del fruto en tomate tipo cereza}
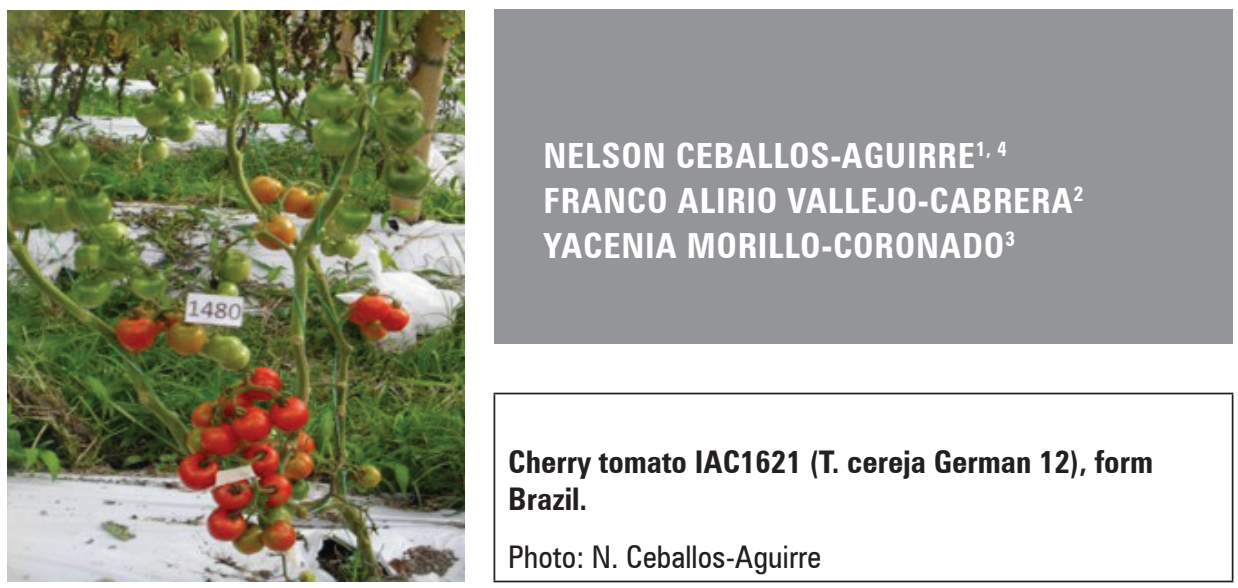

\begin{abstract}
Genotype-environment interactions (GEI) were assessed in 10 cherry tomato accessions in nine environments, including four artificial settings $\left(0,60120\right.$, and $180 \mathrm{~kg} \mathrm{ha}^{-1}$ of potassium) established on the experimental farms Montelindo (Palestina), Tesorito (Manizales), and CEUNP (Palmira) (Colombia). The plant material included 10 cherry tomato genotypes obtained from the germplasm bank at the Instituto Agronómico de Campinas and Tomato Genetics Resources Center (TGRC). A completely randomized block design with four blocks corresponding to the level of potassium fertilization was used (0,60, 120, $\left.180 \mathrm{~kg} \mathrm{ha}^{-1}\right)$; $0 \mathrm{~kg} \mathrm{ha}^{-1}$ was the level reported for the soil. The effective size of the experiment unit was seven plants; the plot included the five central plants. A distance of $1.5 \mathrm{~m}$ between rows, $0.50 \mathrm{~m}$ between plants, and $2 \mathrm{~m}$ between blocks was used. The contents of soluble solids ( $\left.{ }^{\circ} \mathrm{Brix}\right)$, vitamin $\mathrm{C}$ ( $\mathrm{mg} / 100 \mathrm{~g}$ fresh weight), and lycopene $\left(\mu \mathrm{g} \mathrm{g}^{-1}\right.$ fresh weight) were assessed. The analysis of variance (ANOVA) showed significant differences $(P<0.01)$ between the tomato genotypes, environments, and $\mathrm{G} \times \mathrm{E}$ interactions for the three assessed traits. The AMMI analysis identified similar and contrasting environments and determined the genotypes that contributed the most to the GEI. The environments with 120 and $180 \mathrm{~kg} \mathrm{ha}^{-1}$ potassium favored the expression of vitamin C, while Palmira favored the lycopene content. The findings are useful for identifying optimal locations and elite genotypes that can be used as sources of variability in fruit quality improvement programs for cherry tomatoes.
\end{abstract}

\footnotetext{
1 Universidad de Caldas, Facultad de Ciencias Agropecuarias, Manizales (Colombia). ORCID Ceballos-Aguirre, N.: 0000-0002-8463-3379

2 Universidad Nacional de Colombia, Sede Palmira, Palmira (Colombia). ORCID Vallejo-Cabrera, F.A.: 0000-0002-2739-0745

3 Corporación Colombiana de Investigación Agropecuaria-Agrosavia, Palmira (Colombia). ORCID Morillo-Coronado, Y.: 0000-0003-1974-3464

4 Corresponding author.nelson.ceballos@ucaldas.edu.co
} 


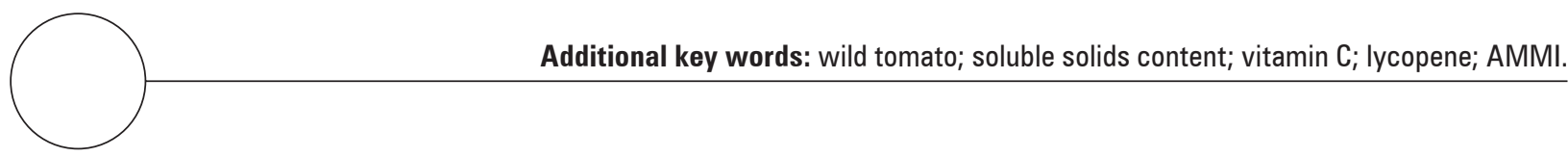

\section{RESUMEN}

Se evaluó la interacción genotipo-ambiente (IGA) de 10 accesiones de tomate cereza en nueve ambientes, los cuales estuvieron conformados por cuatro ambientes artificiales (0, 60120 y $180 \mathrm{~kg} \mathrm{ha}^{-1}$ de potasio) establecidos en ambientes naturales de las Granjas Montelindo (Palestina), Tesorito (Manizales) y CEUNP (Palmira) (Colombia). El material vegetal incluyó diez genotipos de tomate cherry obtenidos de los bancos de germoplasma del Instituto Agronómico de Campinas y del Centro de Recursos Genéticos de Tomate (TGRC). Se utilizó un diseño de bloques completamente al azar con cuatro bloques correspondientes al nivel de fertilización con potasio $(0,60,120,180 \mathrm{~kg}$ $\left.\mathrm{ha}^{-1}\right)$; particularmente, $0 \mathrm{~kg} \mathrm{ha}^{-1}$ es el nivel reportado para el suelo. El tamaño efectivo de la unidad experimental fue de siete plantas; la parcela incluía las cinco plantas centrales. Se estableció una distancia de 1,5 m entre filas, 0,50 m entre plantas y $2 \mathrm{~m}$ entre bloques. Las variables evaluadas fueron: contenido de sólidos solubles ( $\left.{ }^{\circ} \mathrm{Brix}\right)$, contenido de vitamina C (mg/100 g peso fresco) y contenido de licopeno ( $\mu \mathrm{g} \mathrm{g}^{-1}$ peso fresco). El análisis de varianza (ANOVA) reveló diferencias significativas $(P<0.01)$ entre genotipos de tomate, ambientes y su interacción para las tres características evaluadas. El análisis AMMI identificó ambientes semejantes y contrastantes y se discriminó los genotipos que más contribuyeron a la IGA. Los ambientes de 180 y $120 \mathrm{~kg} \mathrm{ha}^{-1}$ de potasio fueron favorables para la expresión del contenido de vitamina C y Palmira para la variable contenido de licopeno. Los resultados encontrados podrían ser de gran utilidad para identificar localidades óptimas y genotipos élite que pueden ser utilizados como fuentes de variabilidad en programas de mejoramiento de la calidad del fruto de tomate.

Palabras clave adicionales: tomate silvestre; contenido de sólidos solubles; vitamina C; licopeno; AMMI.

Received for publication: 29-06-2020 Accepted for publication: 23-11-2020

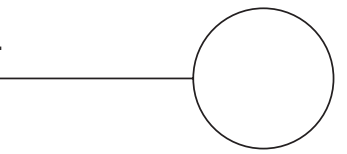

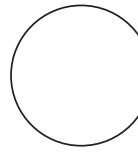

The tomato (Solanum lycopersicum L.) is one of the most cultivated horticultural crops worldwide, with an area of 4.8 million hectares and production that equaled 182 million tons in 2017 (FAOSTAT, 2019). Fruits and vegetables are an important source for the daily requirements of a healthy diet, such as minerals (calcium, phosphorous, magnesium and other minor minerals), water-soluble vitamins (B and $\mathrm{C}$ ), fat-soluble vitamins (A, E and $\mathrm{K}$ ) and a wide variety of phytochemicals (Shahidi et al., 2011). Tomatoes contain considerable levels of vitamins, minerals, and antioxidants that can prevent the development of various cancers, including prostate, colon, and breast cancers through antioxidants, beta-carotene and lycopene (Bai and Lindhout, 2007; Ballon-Landa and Parsons, 2018). Tomato fruits have a considerable amount of ascorbic acid (AA) (or vitamin C), which ranges from 84 to $590 \mathrm{mg} \mathrm{kg}^{-1}$ (Gest et al., 2013; Martí et al., 2018).

Cherry tomato production has increased worldwide because of the significant source of antioxidants that reduce the risk of chronic diseases, and cherry tomatoes are widely used in salads, sauces, and cocktails, resulting in demand in the market (Machado et al., 2003; Córdoba et al., 2018).

According to Ozturk and Ozer (2019), factors such as fertilization and nutrient supply have significant effects on nutritive values and quality in tomatoes. Potassium is a readily mobile element that is required in large amounts by tomatoes (Schwarz et al., 2013) because it participates in plant-water relations, enzyme activation, charge balance of organic and inorganic anions, cytosol $\mathrm{pH}$ regulation, protein synthesis, cell expansion, photosynthesis, stomatal control, and tolerance to biotic and abiotic stresses (Zhao et al., 2018). K appears to be one of the more important nutrients that can positively affect nutritional quality. Increased fertilization with $\mathrm{K}$ induces transpiration and photosynthesis in plants, creating an increase in the production of photoassimilates. In addition, increased fertilization with $\mathrm{K}$ supposes an increase in 
the transport of photoassimilates to fruits, which improves their production and nutritional quality (Constán-Aguilar et al., 2015).

$\mathrm{K}$ fertilization has a positive effect on crop yield in general (Zörb et al., 2014), and some studies have shown a positive effect on tomato yield (Amjad et al., 2014). Diverse studies have also shown an effect of $K$ fertilization on the concentration of certain plant antioxidants, such as carotenoids (Kaur et al., 2018; Tavallali et al., 2018), tocopherols (Caretto et al., 2008), phenolic compounds (Tavallali et al., 2018), and ascorbic acid (Kaur et al., 2018). Some studies have demonstrated increasing levels of antioxidants when $\mathrm{K}$ fertilization is increased (Constán-Aguilar et al., 2015; Tavallali et al., 2018), while others have shown no effect or even a decrease in antioxidant levels (Fanasca et al., 2006; Taber et al., 2008). These diverse results might be due to varying cultivation environments, for example, a greenhouse (Constán-Aguilar et al., 2015) or open field (Taber et al., 2008), along with alternating abiotic factors or different cultivars.

One of the principal aims of genetic improvement in fresh-market tomatoes is enhancing nutritional and organoleptic qualities (Roselló et al., 2000). A lot of effort is made to enhance fruit quality traits in terms of lycopene, soluble solids, and vitamin C contents, along with titratable acidity (Masheva, 2014). However, a tomato genotype that provides high performance and outstanding quality traits in a given location may not necessarily express this potential in a different location. This differential response across different environments results from genotype-byenvironment interactions (GEI) (Panthee et al., 2012).

The variability in yield and performance depends on the productive potential of the environment and the interaction of the genetic potential with the environment (Hortelano et al., 2013). GEI refers to the differential behavior of genotypes under variable environmental conditions. Environmental factors play a relevant role in gene regulation and can affect the expression of genes that control a trait of interest, as well as phenotypic expressions across localities (Panthee et al., 2012). The creation of new genotypes requires the assessment of different environments and measuring the magnitude of genotype-environment interactions, providing insight into the phenotypic stability of genotypes in response to environmental fluctuations (Sánchez et al., 2015).
Crossa (1990) suggested that the application of multivariate methods is useful for exploring genotype-environment interactions and recommended techniques such as principal component analysis (PCA), clustering analysis, and Additive Main Effect and Multiplicative Interaction (AMMI) method. This study aimed to estimate the genotype-environment interaction for internal fruit quality traits in cherry tomatoes.

\section{MATERIALS AND METHODS}

The plant material included 10 cherry tomato genotypes obtained from the germplasm bank of the Universidad de Caldas. The genotypes are described in table 1.

\section{Table 1. Cherry tomato accessions used for estimating $\mathrm{G} \times \mathrm{E}$ interactions.}

\begin{tabular}{|l|c|c|}
\hline Genotype & Description & $\begin{array}{c}\text { Place of } \\
\text { origin }\end{array}$ \\
\hline IAC1621 & T. cereja German 12 & Brazil \\
\hline IAC1624 & T. cereja & Brazil \\
\hline IAC1688 & T."'Lili” cereja & Brazil \\
\hline IAC391 & T. red cherry & Brazil \\
\hline IAC412 & Cherry tomato & Brazil \\
\hline IAC426 & T. cherry Juliet & Brazil \\
\hline IAC445 & T. cereja Jundiai & Brazil \\
\hline LA2076 & Tomate cereza & California \\
\hline LA2692 & Cherry tomato & Peru \\
\hline Sweet Million & $\begin{array}{c}\text { Solanum lycopersicum var. } \\
\text { cerasiforme }\end{array}$ & Control \\
\hline
\end{tabular}

IAC: accessions from the Instituto Agronómico de Campinas, Campinas, Brazil. LA: accessions from the Tomato Genetics Resources Center (TGRC), University of California, Davis.

The assays were established in three natural environments: the Montelindo and Tesorito experimental farms of the Universidad de Caldas, and the Centro Experimental de la Universidad Nacional de Colombia, Palmira Campus (CEUNP) (Tab. 2).

\section{Variables}

Lycopene. $0.6 \mathrm{~g}$ of tomato pulp of each introduction were weighed; then, $5 \mathrm{~mL}$ of acetone-n-hexane (4:6) were added, and the mixture was centrifuged at 5,000 
rpm for 5 min at $4^{\circ} \mathrm{C}$. Afterwards, the optic density of the supernatants was measured using spectrophotometry at $663,645,505$, and $453 \mathrm{~nm}$; the blank was an acetone-n-hexane mixture (Rosales et al., 2009). The lycopene concentration was quantified using the equation proposed by Nagata and Yamashita (1992) (Eq. 1):

[lycopene] $\left(\mu \mathrm{g} \mathrm{mL} \mathrm{mL}^{-1}\right)=\begin{aligned} & 0.0458 \mathrm{~A}_{663}+0.204 \mathrm{~A}_{645}+ \\ & 0.372 \mathrm{~A}_{505}-0.0806 \mathrm{~A}_{453}\end{aligned}$

Fruit acidity and vitamin C. 10 fruits were collected from the second raceme of each introduction and repetition. Approximately $10 \mathrm{~mL}$ of juice were extracted and diluted in $100 \mathrm{~mL}$ of distilled water. To determine the fruit acidity, titration with $0.1 \mathrm{~N} \mathrm{NaOH}$ to a $\mathrm{pH}$ of 8.2 was used, expressed as \% of citric acid. To determine the vitamin $\mathrm{C}$ content, a $0.1 \mathrm{~N}$ iodide solution was used for titration until a color change was noticed (IPGRI, 1996). Finally, the soluble solids content was measured using a refractometer (Hanna Instruments) on a $0.2^{\circ}$ Brix scale.

\section{Experiment design}

We used a completely randomized block design with four blocks corresponding to the level of potassium fertilization $\left(0,60,120,180 \mathrm{~kg} \mathrm{ha}^{-1}\right) ; 0 \mathrm{~kg} \mathrm{ha}^{-1}$ was the level reported for the soil (Tab. 2). On the Tesorito Farm, the environments with potassium levels of 0 , $60,120,180 \mathrm{~kg} \mathrm{ha}^{-1}$ were designated as T0K, T60K, $\mathrm{T} 120 \mathrm{~K}$, and $\mathrm{T} 180 \mathrm{~K}$, respectively. Likewise, on the Montelindo Farm, the environments were named M0K, M60K, M120K, and M180K based on the same potassium levels. Lastly, the Palmira environment was named PAL.

The effective size of the experiment unit was seven plants; the plot included the five central plants. In addition, internal replicas were taken into account because the evaluated variables were taken from the fruits. In this case, at least five fruits were taken per plant, for a total of 25 repetitions within each block, starting from the fruit as an experiment unit, so the information was balanced and maximized to calculate the interaction using the AMMI model in each natural environment with the artificial environments (potassium). Normality and homoscedasticity tests were carried out for the evaluated variables. For crop nutrition, the extraction level of the cultivated species was taken into account for the differential to be applied for all elements (except potassium), calculated according to the contents reported by the soil analysis of each location before establishing the field trials (table 2 shows the reports of the soil analysis for each location).

\section{Table 2. General characteristics and soil nutrient levels of the tested environments for estimating $G \times E$ interactions in cherry} tomatoes.

\begin{tabular}{|c|c|c|c|}
\hline Environment & Montelindo farm & Centro Experimental CEUNP & Tesorito farm \\
\hline Location & Palestina & Candelaria & Manizales \\
\hline Geographic coordinates & $5^{\circ} 04^{\prime} \mathrm{N}, 75^{\circ} 45^{\prime} \mathrm{W}$ & $3^{\circ} 24^{\prime} \mathrm{N}, 76^{\circ} 26^{\prime} \mathrm{W}$ & $5^{\circ} 01^{\prime} 47^{\prime \prime} \mathrm{N}, 75^{\circ} 26^{\prime} 03^{\prime \prime} \mathrm{W}$ \\
\hline Elevation (m) & 1,030 & 980 & 2,340 \\
\hline Mean precipitation (mm) & 2,200 & 1,009 & 2,000 \\
\hline Average temperature $\left({ }^{\circ} \mathrm{C}\right)$ & 23 & 24 & 17.5 \\
\hline $\mathrm{pH}$ & 4.7 & 6.54 & 5.2 \\
\hline Nitrogen (\%) & 0.54 & 0.1 & 0.41 \\
\hline Organic matter (\%) & 14.64 & 2.07 & 10.18 \\
\hline Phosphorus (mg kg-1) & 21 & 227 & 125 \\
\hline Potassium $\left(\mathrm{cmol} \mathrm{kg}^{-1}\right)$ & 0.29 & 0.66 & 0.97 \\
\hline Calcium $\left(\mathrm{cmol} \mathrm{kg}^{-1}\right)$ & 0.82 & 13 & 4.74 \\
\hline Magnesium $\left(\mathrm{cmol} \mathrm{kg}^{-1}\right)$ & 0.19 & 5.84 & 1.27 \\
\hline Iron $\left(\mathrm{mg} \mathrm{kg}^{-1}\right)$ & 189 & 61.5 & 276 \\
\hline Manganese $\left(\mathrm{mg} \mathrm{kg}^{-1}\right)$ & 13.43 & 69.8 & 10.44 \\
\hline Zinc $\left(\mathrm{mg} \mathrm{kg}^{-1}\right)$ & 9.52 & 5.35 & 8.33 \\
\hline Copper (mg kg-1) & 6.52 & 4.71 & 5.33 \\
\hline Sulfur $\left(\mathrm{mg} \mathrm{kg}^{-1}\right)$ & 31.8 & 22.8 & 77.86 \\
\hline Boron $\left(\mathrm{mg} \mathrm{kg}^{-1}\right)$ & 0.1 & 0.53 & 1.1 \\
\hline
\end{tabular}


A distance of $1.5 \mathrm{~m}$ between rows, $0.50 \mathrm{~m}$ between plants, and $2 \mathrm{~m}$ between blocks was used. A blankand-white padded plastic, $0.8 \mathrm{~m}$ wide and 1.2 thick, was used to control weeds. When the fruits reached total maturity ( $65 \mathrm{~d}$ after transplant for Montelindo and CEUNP and $95 \mathrm{~d}$ for Tesorito). The state of maturity in the fruits used a 5 point scale, which, for the cultivated species, was red, guaranteeing a homogeneous state for all accessions when evaluating the variables. It should be clarified that, within the evaluations made, the time from start to harvest and the yield components of the accessions evaluated were estimated, for which the 10 harvests were taken into account (data not presented). In all cases, five fruits were harvested from each of the five plants in the useful plot in each block, as indicated above, generating at least 25 replications for each accession within each block equivalent to the level of potassium.

The following statistical model explains the behavior of a given genotype across the nine tested environments (Eq. 2)

$$
Y_{i j k}=\mu+A_{k}+\left(B_{j}\right)_{k}+G_{i}+(G A)_{i k}+\varepsilon_{i j k}
$$

where, $Y_{i j k}$ is the mean behavior of genotype $i$ in repetition $j$ in environment $k$ for the trait of interest, $\mu$ is the overall mean of the experiments for the nine tested environments, $A_{k}$ is the effect of environment $k,\left(B_{j}\right)_{k}$ is the effect of repetition $j$ in each location $k$; $G_{i}$ is the effect of genotype $i,(G A)_{i k}$ is the effect of the interaction of genotype $i$ in environment $k$, and $\varepsilon_{i j k}$ is the combined experiment error.

The AMMI multivariate analysis is represented by the following equation proposed by Crossa et al. (1990) (Eq. 3)

$$
Y_{i j}=\mu+g_{i}+e_{j}+\sum_{n=1}^{N} \lambda_{k} \gamma_{i k} \delta_{j k}+\rho_{i j}+\varepsilon_{i j}
$$

where, $Y_{i j}$ is the value observed in the $i$-th genotype in the $j$-th environment, $\mu$ is the overall mean, $g_{i}$ and $e_{j}$ are the fixed genotype effects and environmental deviations, respectively; $l_{k}$ is a singular value of the $K$ axis in the PCA, $\gamma_{i k}$ and $\delta_{\mathrm{jk}}$ are genotype and environmental factors, respectively, in the singular vectors associated with $\lambda_{\mathrm{k}}$ from the interaction matrix; $N$ is the number of principal components retained in the model; $\rho_{\mathrm{ij}}$ is the residual GE interaction; and $\varepsilon_{i j}$ is the residual of the model. Finally, the analysis and figures (biplots) were generated using InfoGen (Balzarini and Di Rienzo, 2003).

\section{RESULTS AND DISCUSSION}

\section{Analysis of variance of fruit quality traits}

The results of the individual and combined ANOVA for fruit quality traits of the 10 tomato genotypes across the nine tested environments are shown in tables 3 and 4 .

The highest value for the lycopene content was at CEUNP (Palmira), reaching contents of $157.44 \mu \mathrm{g} \mathrm{g}^{-1}$ fruit, followed by Montelindo with $31.29 \mathrm{\mu g} \mathrm{g}^{-1}$ fruit, which reported warm conditions (Tab. 2 and 3); on the other hand, the vitamin $\mathrm{C}$ content was better on the Montelindo farm, followed by the Tesorito farm and CEUNP with values of 50.40; 45.30 and 36.62 $\mathrm{mg} / 100 \mathrm{~g}$ fresh weight; respectively (Tab. 3).

There were significant differences $(P<0.01)$ between the genotypes, environments, and genotype-environment interactions for the three fruit quality variables.

Table 3. Analysis of variance (ANOVA) for fruit quality variables in 10 cherry tomato genotypes across individual environments.

\begin{tabular}{|l|l|c|c|c|c|c|c|c|c|c|}
\hline \multirow{2}{*}{$\begin{array}{c}\text { Source of } \\
\text { variation }\end{array}$} & \multirow{2}{*}{ DF } & \multicolumn{3}{c}{ Montelindo farm } & \multicolumn{3}{c|}{ Tesorito farm } & \multicolumn{3}{c|}{ CEUNP } \\
\cline { 3 - 12 } & & SSC & VITC & LYC & SSC & VITC & LYC & SSC & VITC & LYC \\
\hline Genotype (G) & 9 & $35.41^{* *}$ & 1041.93 & $519.28^{*}$ & $88.15^{* *}$ & $173.41^{* *}$ & $38.22^{*}$ & $2.30^{* *}$ & $232.18^{* *}$ & $44724.77^{* *}$ \\
\hline Environment (E) & 3 & $1.52^{* *}$ & 653.40 & 126.49 & $4.26^{* *}$ & $3556.49^{* *}$ & $73.75^{* *}$ & $0.01^{* *}$ & $3.29^{* *}$ & $40.57^{* *}$ \\
\hline G×E & 27 & $1.65^{* *}$ & 306.14 & 75.15 & $3.70^{* *}$ & $139.72^{* *}$ & 19.02 & $0.13^{* *}$ & $11.62^{* *}$ & $143.48^{* *}$ \\
\hline Mean & & 5.59 & 50.40 & 31.29 & 5.65 & 45.30 & 9.17 & 4.39 & 36.62 & 157.44 \\
\hline CV (\%) & 11.17 & 50.93 & 48.53 & 13.06 & 17.62 & 41.66 & 12.11 & 34.27 & 45.09 \\
\hline
\end{tabular}

${ }^{*}$ and ${ }^{* *}$ Denote differences at $5 \%$ and $1 \%$ probability, respectively. CV (\%): coefficient of variation. SSC: soluble solids content ('Brix), VITC: vitamin C content (mg/100 $\mathrm{g}$ fresh weight), LYC: lycopene content ( $\mu \mathrm{g} \mathrm{g}^{-1}$ fruit). 
For the soluble solids content (SSC), $62.55 \%$ of the total sum of squares resulted from the genotypic effects, while the $\mathrm{G} \times \mathrm{E}$ interaction and the environmental effects represented 24.20 and $13.25 \%$, respectively. There were significant differences for all the sources of variation, with a mean of $5.55^{\circ}$ Brix (Tab. 4). These findings demonstrated an opportunity for selecting adequate genotypes with high soluble solids contents. Our results showed that SSC enhancement is feasible in improvement programs and that elite genotypes with a high accumulation of soluble solids can be commercialized regardless of the growth conditions used for high phenotypic values.

For the vitamin $\mathrm{C}$ and lycopene contents, $34.37 \%$ and $75.08 \%$ of the total sum of squares, respectively, resulted from the environmental effects. Meanwhile, the genotypic effects represented 11.83 and $1.24 \%$ of the total sum of squares for these same variables. The effects of the $\mathrm{G} \times \mathrm{E}$ interaction resulted in the highest values for the total sum of squares, specifically, $53.80 \%$ for vitamin C and $23.68 \%$ for lycopene. These results indicated that the effects of the environment and the $G \times E$ interaction had a greater influence on these traits than the genotype alone.

The significant genotype-environment interactions in all traits indicated a differential response of the genotypes to the environmental variations in the different locations. This finding demonstrated that the environment plays a relevant role in determining cherry tomato fruit quality. Further, it suggested the need for additional studies on the contribution of different environments, genotypes, and their interactions to the expression of nutritional properties, enabling a more accurate selection of elite genotypes with a higher accumulation of nutritional compounds. Knowledge on the nature of $\mathrm{G} \times \mathrm{E}$ interactions is particularly necessary for developing "high functional value" cultivars with high environmental stability or specific cultivars for particular environments.

Similar results were reported by Panthee et al. (2012), who assessed the magnitude of the $\mathrm{G} \times \mathrm{E}$ interaction and its influence on fruit quality in 42 tomato genotypes in three locations. The authors found significant differences $(P<0.05)$ between genotypes, locations, and the interaction. The genotype-environment interactions were significant for all studied variables, except for the vitamin $\mathrm{C}$ content.

Spaldon et al. (2017) analyzed the stability and G×E interaction of quality traits in 25 tomato genotypes across six environments. The authors found significant $\mathrm{G} \times \mathrm{E}$ interactions for lycopene, beta-carotene, and ascorbic acid contents, while no significant differences were found for number of locules per fruit, pericarp thickness, soluble solids, or $\mathrm{pH}$. Similarly, Cebolla-Cornejo et al. (2011); Sánchez et al. (2015); and Savale and Patel (2017) among others also reported significant differences in quality traits because of GxE interactions. By contrast, Patel et al. (2017) found that the genotype $\mathrm{x}$ environments interaction was highly significant for all characteristics except fruit $\mathrm{pH}$, reducing sugar (\%), total sugar (\%), lycopene content $(\mathrm{mg} / 100 \mathrm{~g})$ and viscosity $(\mathrm{cSt})$ with a stability analysis of quality parameters in tomatoes (Solanum lycopersicum L.).

\section{Analysis of the genotype-environment interaction with the AMMI model}

The AMMI analysis indicated that the first principal component for SSC was the only significant component, explaining the effect of the interaction, as indicated by a value greater than one. Specifically, PC1 accounted for $66 \%$ of the genotype interactions in

Table 4. Analysis of variance (ANOVA) for fruit quality variables in 10 cherry tomato genotypes across nine environments.

\begin{tabular}{|c|c|c|c|c|c|c|c|c|c|c|}
\hline \multirow{2}{*}{$\begin{array}{l}\text { Source of } \\
\text { variation }\end{array}$} & \multirow{2}{*}{ D.f. } & \multicolumn{3}{|c|}{ Soluble solids content ( ${ }^{\circ}$ Brix) } & \multicolumn{3}{|c|}{ Vitamin C (mg/100 g fresh weight) } & \multicolumn{3}{|c|}{ Lycopene ( $\mu \mathrm{g} / \mathrm{g}$ fruit) } \\
\hline & & SS & MS & $\%$ SS & SS & MS & $\%$ SS & SS & MS & $\%$ SS \\
\hline Environment (E) & 8 & 184.96 & $23.12^{* *}$ & 13.25 & 20951.68 & $2618.96^{* *}$ & 34.37 & 863672.88 & $107959.11^{* *}$ & 75.08 \\
\hline Genotype (G) & 9 & 872.91 & $96.99 * *$ & 62.55 & 7212.42 & $801.38^{* *}$ & 11.83 & 14255.55 & $1583.95^{* *}$ & 1.24 \\
\hline GxE & 72 & 337.68 & $4.69^{* *}$ & 24.20 & 32801.76 & $455.58^{* *}$ & 53.80 & 272413.44 & $3783.52^{* *}$ & 23.68 \\
\hline Mean & & \multicolumn{3}{|c|}{5.55} & \multicolumn{3}{|c|}{42.42} & \multicolumn{3}{|c|}{63.21} \\
\hline CV (\%) & & \multicolumn{3}{|c|}{11.95} & \multicolumn{3}{|c|}{13.25} & \multicolumn{3}{|c|}{8.21} \\
\hline
\end{tabular}

** Significant differences at 1\% probability. D.f.: degrees of freedom, SS: Sum of squares, MS: mean of squares, \%SS: percent of the sum of squares, CV (\%): coefficient of variation. 
the tested environments. Moreover, the vitamin C and lycopene contents had three significant principal components with values greater than one; the first two principal components in the AMMI biplot explained 80 and $89 \%$ of the interaction, respectively.

Table 5 shows the mean values for the SSC, vitamin $\mathrm{C}$ content, and lycopene content for each genotype in each environment, as well as the coordinates of the principal components for the genotypes and the nine environments. In addition, figures 1, 2, and 3 show the biplots for these variables.

For the soluble solids content, an overall average of $5.51{ }^{\circ}$ Brix was obtained for the genotypes, with a minimum value of $4.28{ }^{\circ}$ Brix for genotype IAC412 and a maximum value of $7.03{ }^{\circ} \mathrm{Brix}$ for the control Sweet Million. All environments favored SSC, except PAL (Palmira - CEUNP farm), which had the lowest value $\left(4.40{ }^{\circ} \mathrm{Brix}\right)$. The more favorable environments for this trait had 60,120 , and $180 \mathrm{~kg} \mathrm{ha}^{-1}$ potassium levels on the Tesorito farm (T60K, T120K, and T180K), which had values of 5.92, 5.73, and 5.70 ${ }^{\circ}$ Brix, respectively $(P<0.05)$. The environment with $120 \mathrm{~kg} \mathrm{ha}^{-1}$ of potassium on the Montelindo farm (M120K) had values close to those previously mentioned. Therefore, potassium levels between 60 and $120 \mathrm{~kg} \mathrm{ha}^{-1}$ in cold (Tesorito) and warm (Montelindo) environments are recommended for enhancing or guaranteeing that genotypes express their optimal SSC. The genotypes IAC391, IAC1621, and IAC1688, as well as the control, are recommended for cultivation in the majority of the environments (except Palmira); these genotypes are expected to perform better with adequate and balanced fertilization with potassium levels between 60 and $120 \mathrm{~kg} \mathrm{ha}^{-1}$ (Tab. 5).

A macro-environment was identified for SSC, comprising the $\mathrm{T} 0 \mathrm{~K}, \mathrm{M} 0 \mathrm{~K}$, and $\mathrm{M} 60 \mathrm{~K}$ environments, which had poor participation in the effect of the interaction, as indicated by the positive PC1 values and values close to zero for PC2. The genotypes associated with these environments were IAC391, IAC426, LA2076, and LA2692, which displayed SSC values

Table 5. Average values and coordinates of the principal components for the genotypes and environments for the cherry tomato quality traits.

\begin{tabular}{|c|c|c|c|c|c|c|c|c|c|}
\hline Genotype & $\begin{array}{l}\text { Soluble solids } \\
\text { content ( }{ }^{\circ} \text { Brix) }\end{array}$ & PC1 & PC2 & $\begin{array}{c}\text { Vitamin C } \\
\text { content }\end{array}$ & PC1 & PC2 & $\begin{array}{l}\text { Lycopene content } \\
\text { ( } \mu \mathrm{g} / \mathrm{g} \text { fruit) }\end{array}$ & PC1 & PC2 \\
\hline $\operatorname{IAC1621~(1)*~}$ & 6.11 & -1.16 & -0.89 & 45.54 & -27.06 & 5.09 & 34.66 & -22.58 & -3.83 \\
\hline IAC1624 (2) & 4.89 & 0.7 & 0.32 & 50.71 & 45.05 & -19.1 & 41.09 & 36.49 & 2.28 \\
\hline IAC1688 (3) & 6.30 & -0.96 & 0.88 & 48.67 & -15.97 & -0.24 & 37.55 & 61.37 & 4.99 \\
\hline IAC391 (4) & 5.57 & 0.09 & -0.06 & 42.61 & -14.31 & 9.82 & 17.97 & -0.6 & -26.26 \\
\hline IAC412 (5) & 4.28 & 1.85 & -0.6 & 42.33 & -53.6 & -25.43 & 12.35 & -75.07 & -21.21 \\
\hline IAC426 (6) & 5.65 & 0.19 & -0.29 & 36.56 & -18.63 & 6.37 & 43.68 & -3.36 & 26.25 \\
\hline IAC445 (7) & 5.29 & 0.99 & 0.34 & 48.96 & -17.54 & 32.12 & 30.87 & -35.79 & 40.01 \\
\hline LA2076 (8) & 5.07 & -0.12 & 0.29 & 51.10 & 34.78 & -26.11 & 25.07 & -19.49 & -13.35 \\
\hline LA2692 (9) & 4.96 & 0.56 & 0.17 & 37.31 & -23 & 1.91 & 47.23 & 128.02 & -7.29 \\
\hline Control (10) & 7.03 & -2.14 & -0.16 & 61.86 & 90.27 & 15.57 & 25.56 & -68.98 & -1.59 \\
\hline TOK & 5.54 & -0.02 & -0.22 & 27.71 & -0.17 & 0.14 & 9.53 & -0.12 & -0.12 \\
\hline T60K & 5.92 & -0.43 & -0.29 & 49.72 & -0.16 & -0.17 & 11.29 & -0.1 & -0.16 \\
\hline T120K & 5.73 & -0.22 & 0.6 & 50.79 & 0.0015 & -0.11 & 7.93 & -0.09 & -0.2 \\
\hline T180K & 5.70 & -0.54 & -0.08 & 52.33 & -0.16 & -0.00067 & 8.06 & -0.14 & -0.2 \\
\hline MOK & 5.52 & 0.12 & -0.12 & 44.95 & -0.37 & -0.4 & 28.70 & -0.17 & -0.07 \\
\hline M60K & 5.52 & 0.16 & -0.15 & 49.40 & -0.07 & 0.64 & 33.98 & -0.09 & -0.19 \\
\hline M120K & 5.68 & 0.32 & -0.44 & 45.12 & 0.3 & 0.46 & 34.70 & -0.1 & 0.91 \\
\hline M180K & 5.49 & 0.02 & 0.47 & 62.12 & 0.81 & -0.35 & 27.78 & -0.11 & 0.05 \\
\hline PAL & 4.40 & 0.58 & 0.23 & 36.33 & -0.19 & -0.2 & 134.08 & 0.94 & -0.01 \\
\hline
\end{tabular}

${ }^{*}$ The numbers in parenthesis represent the same genotype in the biplots in figures 1, 2, and 3. Vitamin $\mathrm{C}$ in $\mathrm{mg} / 100 \mathrm{~g}$ fresh weight. 

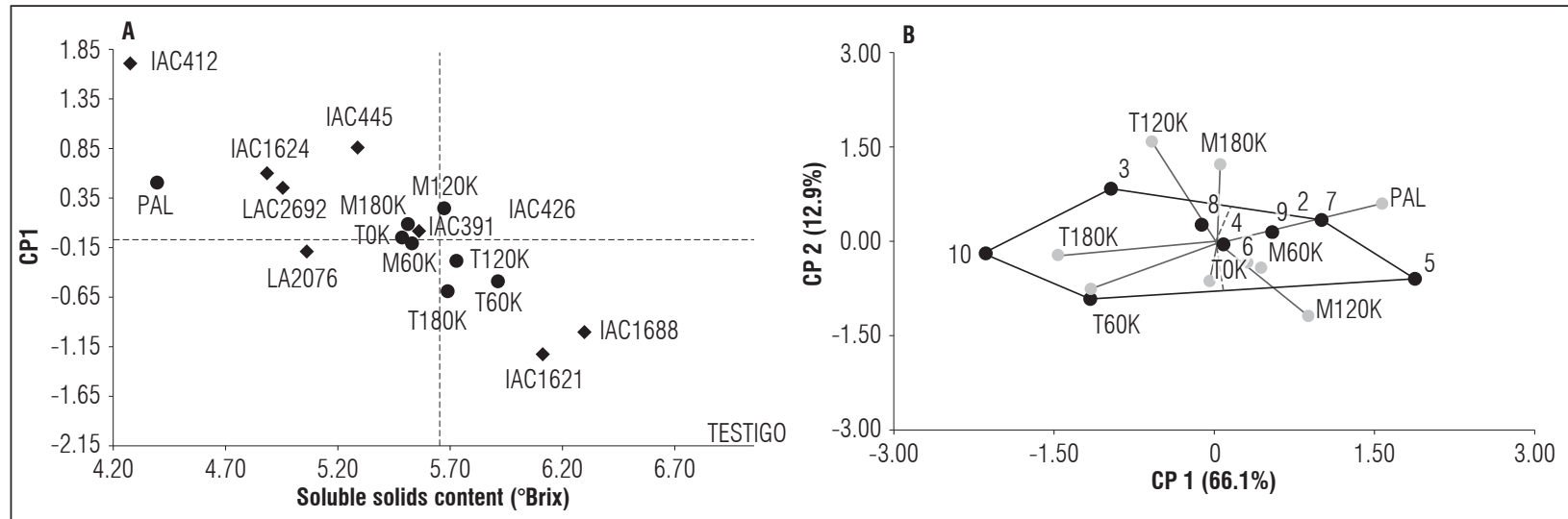

Figure 1. Distribution of 10 tomato genotypes (A) across the 9 tested environments (B) for soluble solids content.

above $5.07^{\circ} \mathrm{Brix}$, except for LA2692 $\left(4.96^{\circ} \mathrm{Brix}\right)$. The environments with the highest interactions were PAL, M120K, T60K, and T180K, which demonstrated high degrees of associations with the vertex genotypes IAC445, IAC412, and IAC1621 and the control (5.10, 5.48, 7.16, and $8.58^{\circ}$ Brix, respectively) (Tab. 5; Fig. $1 \mathrm{~A}, \mathrm{~B})$.

Caretto et al. (2008) reported that an increased SSC in fruits with increased $\mathrm{K}$ levels confirmed the important role $\mathrm{K}$ plays in the configuration of quality profiles in tomato fruits. Wuzhong (2002) reported that an increase in $\mathrm{K}$ fertilizer applications increased the sugar content tomato fruits, resulting in a higher import and accumulation of sugar that enhanced the SSC content in tomato fruits (Balibrea et al., 2006). Contrary to the current findings, Al-Moshileh et al. (2017) reported that $\mathrm{k}$ applications did not have a significant effect on SSC in tomatoes. Similarly, Amjad et al. (2014) reported that K applications significantly induced fruit diameter. This could be ascribed to the activation of enzymes by $\mathrm{K}$ and its involvement in adenosine triphosphate (ATP) production, which is important in regulating the rate of photosynthesis, which enables plants to have more food to be stored in fruits (Havlin et al., 2005).

The content of vitamin $\mathrm{C}$ ranged between 36.56 $\mathrm{mg} / 100 \mathrm{~g}$ fresh weight for IAC426 and $61.86 \mathrm{mg} / 100$ $\mathrm{g}$ fresh weight for the control, with an overall genotype average of $46.57 \mathrm{mg} / 100 \mathrm{~g}$ fresh weight. A positive relationship was observed between the environment and increasing levels of potassium on the Tesorito and Montelindo farms. Accordingly, the most favorable environment was M180K, followed by $\mathrm{T} 180 \mathrm{~K}$, yielding vitamin $\mathrm{C}$ contents of 62.12 and $52.33 \mathrm{mg} / 100 \mathrm{~g}$ fresh weight in fruits, respectively.
The T120K, T60K, and M60K environments promoted vitamin $\mathrm{C}$ contents that exceeded the overall average for the nine environments $(46.50 \mathrm{mg} / 100 \mathrm{~g}$ fresh weight). The ideal genotypes in the three environments were IAC1624, LA2076, and the control, which displayed values of 50.71, 51.10, and 61.86 $\mathrm{mg} / 100 \mathrm{~g}$ fresh weight, respectively. The remaining genotypes were classified according to their best responses under unfavorable environments, namely Palmira, T0K, and M0K (Tab. 5).

The environments with the highest participation in the interaction effect on the vitamin $\mathrm{C}$ content were M0K, M60K, M120K, and M180K, which had the highest absolute values for PC1 and PC2. M60K and M180K were most favorable for the vitamin C content, as indicated by values of 49.4/100 and 62.12 $\mathrm{mg} / 100 \mathrm{~g}$ fresh weight, respectively. Moreover, a macro-environment was identified, with Palmira and Tesorito (with all potassium levels), which had the lowest participation in the interaction effect, as indicated by absolute values close to zero for PC1 and PC2. Therefore, one of these environments could be discarded without affecting the accuracy of the results (Tab. 5; Fig. 2 A, B).

Overall, our results suggested that SSC in cherry tomatoes needs an ideal combination of natural (warm climate) and artificial (mineral nutrients) environments, particularly with the optimal potassium level of $180 \mathrm{~kg} \mathrm{ha}^{-1}$ for the vertex genotypes IAC1624 and LA2076 and the commercial control (exceeding 100 $\mathrm{mg} / 100 \mathrm{~g}$ fresh weight). Accordingly, these genotypes improved their response for the vitamin $\mathrm{C}$ content under more suitable environments in terms of climate and nutrition. Moreover, the genotypes IAC1621 (1), IAC1688 (3), IAC391 (4), IAC426 (6), and LA2692 (9) 


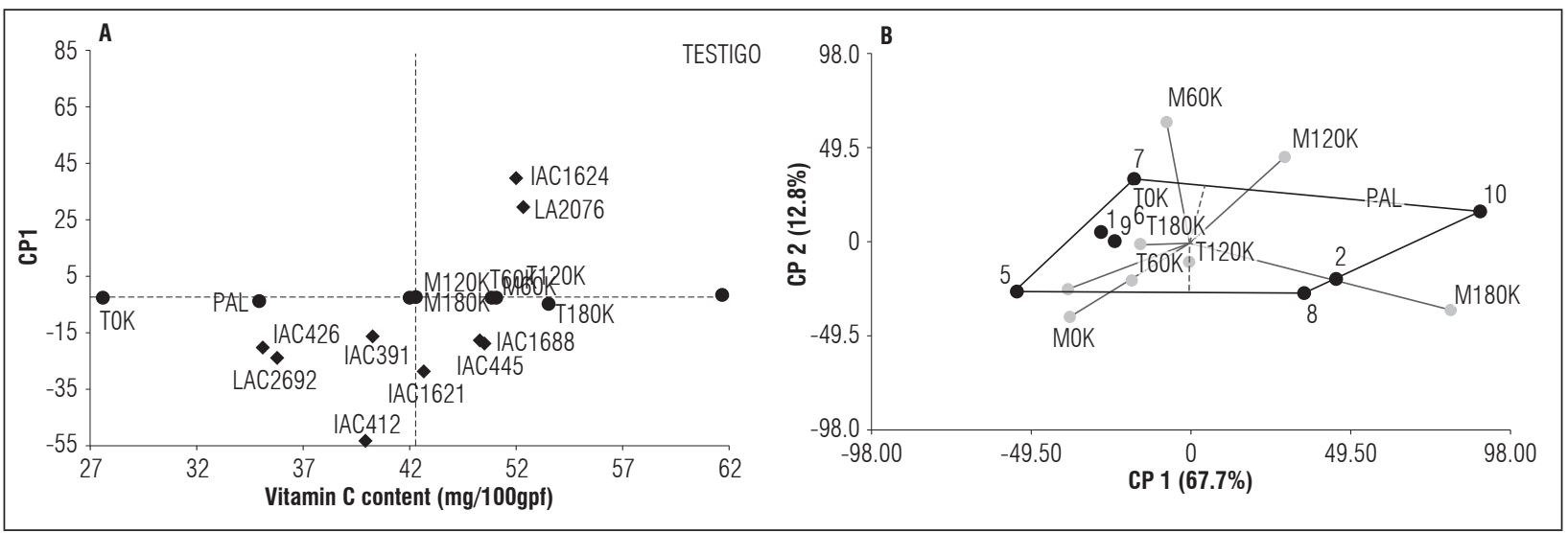

Figure 2. Distribution of the 10 genotypes (A) across 9 tested environments (B) for vitamin $C$ content.

had small interactions, as indicated by absolute values close to zero for PC1 and PC2. Therefore, these genotypes were more stable across the environments. On the other hand, the vertex genotypes IAC412 and IAC445 were specific and had high interactions with the M0K and M60K environments, respectively. These genotypes reached the highest phenotypic expressions of vitamin $\mathrm{C}$ content in each corresponding environment, as indicated by values of $90.78 \mathrm{mg} / 100 \mathrm{~g}$ fresh weight and $95.23 \mathrm{mg} / 100 \mathrm{~g}$ fresh weight, respectively (Fig. 2 A, B).

Woldemariam et al. (2018) assessed the effect of potassium levels (0, 50, 100, 150, 200, 250, 300, 350 and $400 \mathrm{~kg} \mathrm{ha}^{-1}$ of $\mathrm{K}_{2} \mathrm{O}$ ) on productivity and fruit quality in tomatoes. The results of this study revealed that potassium had a significant effect on all yield and quality parameters. The fruit diameter, fruit weight per plant, total yield, total soluble solids, specific gravity and fruit dry matter content had a significant increase with the increased potassium levels, from 0 to $150 \mathrm{~kg} \mathrm{ha}^{-1}$ of $\mathrm{K}_{2} \mathrm{O}$, after which they decreased. The fruit moisture content increased in the range of $150-400 \mathrm{~kg} \mathrm{ha}^{-1}$ of $\mathrm{K}_{2} \mathrm{O}$. As a result, the highest fruit weight $(1.39 \mathrm{~kg} /$ plant $)$, fruit yield $\left(15.45 \mathrm{t} \mathrm{ha}^{-1}\right)$, total soluble solids ( $\left.3.84{ }^{\circ} \mathrm{Brix}\right)$, specific gravity (1.46) and fruit dry matter $(5.68 \%)$ were recorded with $150 \mathrm{~kg}$ $\mathrm{K}_{2} \mathrm{O} / \mathrm{ha}$.

Rebouças Neto et al. (2016) assessed the effects of potassium (K) drip fertigation and conventional $\mathrm{K}$ fertilization on tomato crop quality. They find that Potassium fertilization applied through fertigation (400 kg ha-1 of $\mathrm{K}_{2} \mathrm{O}$ ) increased the content of soluble solids and the ratio between soluble solids and titratable acidity in tomato fruits.
Wang et al. (2009) conducted a greenhouse pot study that compared the effects of different rates of $\mathrm{K}$ (using a $\mathrm{KCl}$ source) on cherry tomato quality parameters, finding that rates between 1.4 and $3 \mathrm{mmol} \mathrm{KCl}$ were ideal for the soluble solid content. Potassium fertilization rates (in the form of $\mathrm{KCl}$ ) had a positive effect on SSC in drip irrigated processing tomatoes (García, 2012).

Finally, the lycopene content ranged from $12.35 \mu \mathrm{g}$ $\mathrm{g}^{-1}$ fruit for genotype IAC412 and $47.23 \mu \mathrm{g} \mathrm{g}^{-1}$ fruit for genotype LA2692, with an overall genotype average of $31.6 \mu \mathrm{g} \mathrm{g}^{-1}$ fruit. Our findings are supported by Cantore et al. (2008) and Dar and Sharma (2011), who reported high variability in lycopene and betacarotene contents in cherry tomatoes. The best response of the lycopene content was observed in the PAL environment, yielding $134.08 \mu \mathrm{g} \mathrm{g}^{-1}$ fruit, followed by M60K and M120K with values of 33.98 and $34.70 \mathrm{\mu g} \mathrm{g}^{-1}$ fruit, respectively. These results showed a relationship between the lycopene content and warm climates / balanced potassium fertilization levels. With the null ( $0 \mathrm{~kg} \mathrm{ha}^{-1}$ potassium) and excess $(180 \mathrm{~kg}$ $\mathrm{ha}^{-1}$ potassium) fertilization levels, the environments did not favor the expression of the lycopene content. Moreover, the cold environments (with an average temperature of $17.5^{\circ} \mathrm{C}$ ) were the most unfavorable for the lycopene content (Tab. 5).

Constán-Aguilar et al. (2014), in their study to determine whether the effect of a biofortification program with $\mathrm{K}$ in $\mathrm{KCl}$ form can improve the postharvest storage of cherry tomato fruits at $4^{\circ} \mathrm{C}$, found that the treatment with $15 \mathrm{mM} \mathrm{KCl}$ prevented weight and water losses during postharvest storage at $4^{\circ} \mathrm{C}$, increased the $\mathrm{K}$ concentration, and bolstered the 
antioxidant capacity because the concentration in the lycopene, flavonoids and derivatives rose, while the contents in the Vitamin C, hydroxycinnamic acids and derivatives remained stable.

The study of the effect of potassium fertilization on the concentration of antioxidants in two tomato cultivars during two consecutive years was analyzed by Sonntag et al. (2020), who found that antioxidants in tomato fruits can be affected by potassium fertilization, but other abiotic factors can be reduced or even reverse these effects when cultivation takes place in an uncontrolled outdoor environment. The most consistent $\mathrm{K}$ fertilization effects were found for the naringenin, p-coumaric acid, and caffeic acid. However, the enrichment of tomatoes with antioxidants through $\mathrm{K}$ fertilization depends on the crop and the environment; generalities should be avoided.

Leyva et al. (2013) stated that light and temperature are the most important environmental factors that influence the nutritional content of tomatoes. Further, the authors reported that tomato phytonutrients, such as vitamin C, carotenes, and phenols, are greatly affected by light intensity, duration, and quality. Similarly, Dumas et al. (2003) indicated that lycopene and vitamin $C$ contents are affected by crop production conditions, including temperature, light, fertilization, salinity, and irrigation.

The environments with the greatest magnitude of interaction on lycopene content were PAL and M120K. The former showed the highest degree of association with specific genotypes LA2692, IAC1624, and IAC1688, which obtained average lycopene contents of $47.23,41.09$, and $37.55 \mu \mathrm{g} \mathrm{g}^{-1}$ fruit, respectively. The remaining environments, except for M180K, formed a macro-environment characterized by absolute values close to zero, indicating low participation in the interaction. Particularly, M180K was more closely related to M120K and was associated with the genotypes IAC426 and IAC445, displaying average lycopene contents of 70.25 and $73.11 \mu \mathrm{g} \mathrm{g}^{-1}$ fruit, respectively.

The vertex genotypes with greater interactions were LA2692 (9), IAC412 (5), Control (10), IAC445 (7), and IAC426 (6). Genotypes 9, 7, and 6 were associated with specific environments; genotype IAC412 (5) was most related to the M60K environment, and the control performed best in $\mathrm{MOK}$, where it reached a lycopene content of $53.34 \mu \mathrm{g} \mathrm{g}^{-1}$ fruit (Fig. $3 \mathrm{~A}, \mathrm{~B}$ ).

The production system affects the response of secondary metabolites in tomatoes. Genotype assays conducted under field and greenhouse conditions showed that the highest levels of lycopene were obtained in the field and were significantly different from those found under greenhouse conditions (Böhm, 2004). Our results confirmed previous reports since the lower lycopene contents were observed under semi-greenhouse conditions on the Tesorito farm (with its artificial environments).

Cebolla-Cornejo et al. (2011) stated that variations in total soluble solids and lycopene contents under controlled conditions are attributed to temperature and light intensity effects. These authors found that there was more temperature variation in tomato crops under protected conditions than under field conditions because of a reduced air flow.
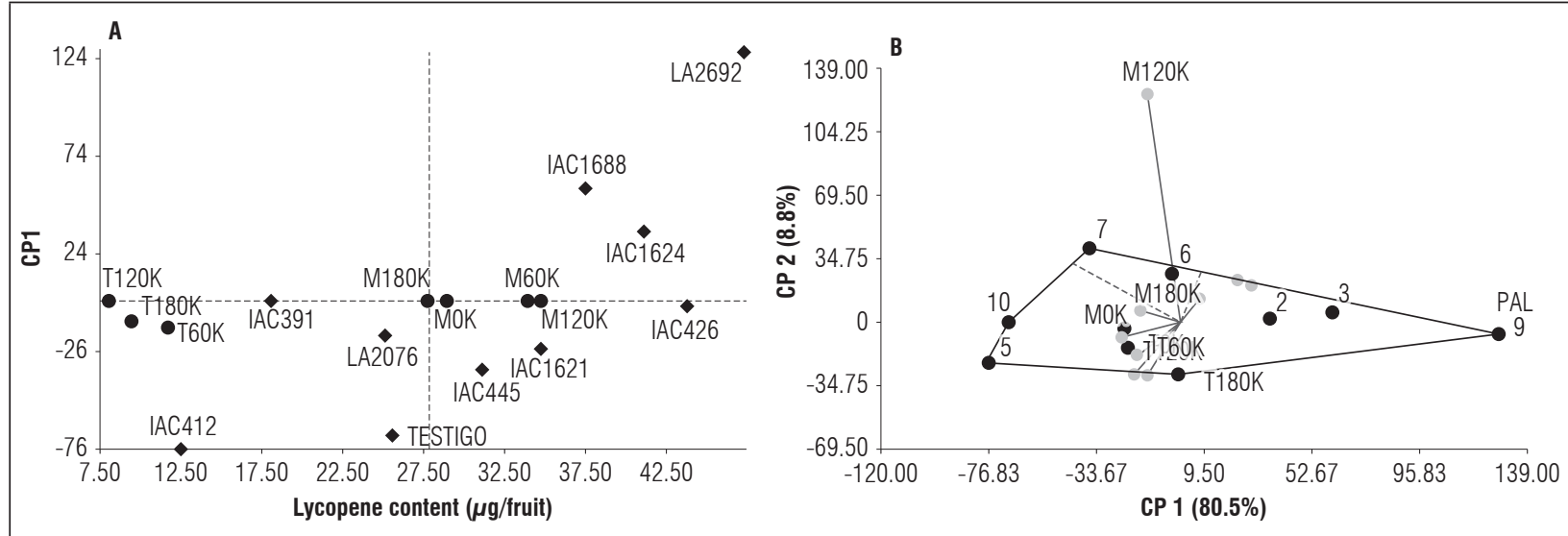

Figure 3. Distribution of the 10 tomato genotypes (A) across 9 tested environments (B) for lycopene content. 
Böhm (2004) studied tomatoes grown under a temperature range of 13.9 to $25.6^{\circ} \mathrm{C}$ and found that the lycopene concentration increased with temperature. In our study, the same genotypes showed highly significant differential responses in the tested environments; in particular, the lycopene content was favored in the environments with an average temperature of $22^{\circ} \mathrm{C}$, such as Palmira and Montelindo. Likewise, Sánchez et al. (2015) found that high temperatures in three tested environments significantly influenced lycopene and vitamin C contents in tomato genotypes. Moreover, according to Luna-Guevara and Delgado-Alvarado (2014), precursors of lycopene are inhibited below $12^{\circ} \mathrm{C}$ and above $32^{\circ} \mathrm{C}$, with an optimal range between 22 and $25^{\circ} \mathrm{C}$ for the production of this pigment.

In general, the fertilizations of 120 and $180 \mathrm{~kg} \mathrm{ha}^{-1}$ of potassium favored the concentrations of vitamin $\mathrm{C}$ and lycopene under certain environmental conditions. This was possibly due to the fact, as mentioned by some authors, that there was a positive correlation between the concentration of lycopene in tomatoes and potassium fertilization (Taber et al., 2008). This close relationship between potassium fertilization and concentration of lycopene in tomatoes seems to be related to the enzymatic activation function exerted by K; more than one enzyme in the metabolism of lycopene synthesis has the $\mathrm{K}$ activation cofactor, including phytoene desaturase or phytoene synthase, an enzyme that catalyzes the reaction of phytoene synthase from geranylgeranyl diphosphate, which is the first step in the carotenoid synthesis pathway (Rodriguez-Amaya, 2001; Ramírez et al., 2012). Ahmad et al. (2015) stated that K applications significantly increased tomato yield, and a $35.55 \%$ yield advantage over the control was obtained from applications of $120 \mathrm{~kg} \mathrm{ha}^{-1}$ of $\mathrm{K}_{2} \mathrm{O}$. This could be due to the fact that sufficient $\mathrm{K}$ supplements help plants in efficient photosynthetic activities and translocation of photosynthates from sites of production to storage organs (Abd El-Latif et al., 2011; Patil, 2011).

Several earlier studies have also shown a positive relationship between $\mathrm{K}$ applications and ascorbic acid concentrations in tomatoes (Constán-Aguilar et al., 2015; Tavallali et al., 2018), while others did not observe this effect (Fanasca et al., 2006) or found it to be cultivar-dependent (Schwarz et al., 2013). Nutrition with adequate $\mathrm{K}$ is also associated with a greater yield, larger fruit size, increased soluble solids, higher Vitamin C concentrations and improved fruit color
(Kanai et al., 2007). Additionally, $\mathrm{K}$ is involved in post-harvest quality of vegetables and fruits; it is associated with quality in products with a plant origin because of its important effects on post-harvest attributes, such as color, size, acidity, resistance to transportation, handling, storage, nutritional value, and industrial qualities (Javaria et al., 2012).

Woldemariam et al. (2018) assessed the effect of potassium levels $(0,50,100,150,200,250,300,350$ and $400 \mathrm{~kg} \mathrm{ha}^{-1}$ of $\mathrm{K}_{2} \mathrm{O}$ ) on productivity and fruit quality in tomatoes. The results of this study revealed that potassium had a significant effect on all yield and quality parameters. The fruit diameter, fruit weight per plant, total yield, total soluble solids, specific gravity and fruit dry matter content had significant increases with increased potassium levels, from 0 to $150 \mathrm{~kg} \mathrm{ha}^{-1}$ of $\mathrm{K}_{2} \mathrm{O}$, and thereafter decreased while the fruit moisture content increased in the range of $150-400 \mathrm{~kg} \mathrm{ha}^{-1}$ of $\mathrm{K}_{2} \mathrm{O}$. As a result, the highest fruit weight $\left(1.39 \mathrm{~kg} /\right.$ plant), fruit yield $\left(15.45 \mathrm{t} \mathrm{ha}^{-1}\right)$, total soluble solids (3.84 $\left.{ }^{\circ} \mathrm{Brix}\right)$, specific gravity (1.46) and fruit dry matter (5.68\%) were recorded with 150 $\mathrm{kg} \mathrm{ha}^{-1}$ of $\mathrm{K}_{2} \mathrm{O}$. Increases in tomato yield, growth and fruit quality with different doses and sources of $\mathrm{K}$, in balance with other micronutrients, have also been reported by Khan et al. (2014), Armita et al. (2017) and Hernández-Pérez et al. (2019).

\section{CONCLUSIONS}

The nine tested environments greatly influenced the phenotypic expression of the cherry tomato quality traits. However, the greatest contribution came from the effects of the environment through considerable $\mathrm{G} \times \mathrm{E}$ interactions. The significant genotypic differences in the lycopene, vitamin $\mathrm{C}$, and soluble solids contents showed that some genotypes possess outstanding genetic potential for these functional properties. Furthermore, these genotypes can be used as parent plants in future tomato improvement programs or for direct consumption in fruit quality markets.

Positively correlated environments, vectors in the same direction, and negatively correlated environments were identified. Our findings identify key environments for better discriminating genotypes and developing cultivars with broad adaptability, high performance, and excellent nutritional quality across multiple environments. 


\section{ACKNOWLEDGMENTS}

The authors thank the Universidad Nacional de Colombia, Palmira, Faculty of Agricultural Sciences Graduate School, the Vice-Rector's Office for Research and Postgraduate Studies and Agricultural Sciences of the Universidad de Caldas for funding this study.

Conflict of interests: The manuscript was prepared and reviewed with the participation of the authors, who declare that there exists no conflict of interest that puts at risk the validity of the presented results.

\section{BIBLIOGRAPHIC REFERENCES}

Abd El-Latif, K.M., E.A.M. Osman, R. Abdullah, and N.A. Kader. 2011. Response of potato plants to potassium fertilizer rates and soil moisture deficit. Adv. Appl. Sci. Res. 2, 388-397.

Ahmad, N., M. Sarfraz, U. Farooq, M. Arfan-ul-Haq, M.Z. Mushtaq, and M.A. Ali. 2015. Effect of potassium and its time of application on yield and quality of tomato. Int. J. Sci. Res. Pub. 5(9), 1-4.

Al-Moshileh, A.M., M.A. Errebhi, and H.A. Obiadalla-Ali. 2017. Effect of potassium fertilization on tomato and cucumber plants under greenhouse conditions. Biosci. Res. 14(1), 68-74.

Amjad, M., J. Akhtar, M. Anwar-Ui-Haq, S. Imran, and S. Jacobsen. 2014. Soil and foliar application of potassium enhances fruit yield and quality of tomato under salinity. Turk. J. Biol. 38, 208-218. Doi: 10.3906/ biy-1305-54

Armita, D., A.P. Rahayu, M.D. Maghfoer, and D.A.F. Fuadi. 2017. Effect of potassium fertilization on the yield and quality of two tomato varieties. Biosci. Res. 14(4), 1150-1155.

Bai, Y. and P. Lindhout. 2007. Domestication and breeding of tomatoes: what have we gained and what can we gain in the future? Ann. Bot. 100(5), 1085-1094. Doi: 10.1093/aob/mcm150

Balibrea, M.E., C. Martínez-Andújar, J. Cuartero, M.C. Bolarín, and F. Pérez-Alfocea. 2006. The high fruit soluble sugar content in wild Lycopersicon species and their hybrids with cultivars depends on sucrose import during ripening rather than on sucrose metabolism. Funct. Plant Biol. 33(3), 279-288. Doi: 10.1071/FP05134

Ballon-Landa, E. and J.K. Parsons. 2018. Nutrition, physical activity, and lifestyle factors in prostate cancer prevention. Curr. Opin. Urol. 28, 55-61. Doi: 10.1097/ MOU.0000000000000460

Balzarini, M.G. and J.A. Di Rienzo. 2003. Infogen: Software para análisis estadísticos de marcadores genéticos.
Facultad de Ciencias Agropecuarias. Universidad Nacional de Córdoba, Cordoba, Argentina.

Böhm, V. 2004. Effects of agronomic practices and processing conditions on tomato ingredients. pp. 37-46. In: Dris, R. and S.M. Jain (eds.). Production practices and quality assessment of food crops. Preharvest Practice 1. Doi: 10.1007/1-4020-2533-5_2

Cantore, V., F. Boari, S. Vanadia, B. Pace, E-de Palma, L. Leo, and G. Zacheo. 2008. Evaluation of yield and qualitative parameters of high lycopene tomato cultivars. Acta Hortic. 789, 173-180. Doi: 10.17660/ ActaHortic.2008.789.24

Caretto, S., A. Parente, F. Serio, and P. Santamaria. 2008. Influence of potassium and genotype on vitamin E content and reducing sugar of tomato fruits. HortScience 43(7), 2048-2051. Doi: 10.21273/HORTSCI.43.7.2048

Cebolla-Cornejo, J., S. Rosello, M. Valcarcel, E. Serrano, J. Beltran, and F. Nuez. 2011. Evaluation of genotype and environment effects on taste and aroma flavor components of Spanish fresh tomato varieties. J. Agr. Food Chem. 59(6), 2440-2450. Doi: 10.1021/jf1045427

Constán-Aguilar, C., R. Leyva, L. Romero, T. Soriano, B. Blasco, and M. Ruiz. 2015. The effect of potassium biofortification over yield and nutritional quality of cherry tomato fruits. Am. J. Adv. Food Sci. Technol. Doi: 10.7726/ajafst.2015.1006

Constán-Aguilar, C., R. Leyva, L. Romero, T. Soriano, and J.M. Ruiz. 2014. Implication of potassium on the quality of cherry tomato fruits after postharvest during cold storage. Int. J. Food Sci. Nutr. 65(2), 203-211. Doi: 10.3109/09637486.2013.839632

Córdoba, H.A., S.V. Gómez, and C.E. Nústez. 2018. Evaluación del rendimiento y fenología de tres genotipos de tomate cherry (Solanum lycopersicum L.) bajo condiciones de invernadero. Rev. Colomb. Cienc. Hortic. 12(1), 113-125. Doi: 10.17584/rcch.2018v12i1.7348

Crossa, J. 1990. Statistical analysis of multilocation trials. Adv. Agron. 44, 55-85. Doi: 10.1016/ S0065-2113(08)60818-4

Crossa, J., H.G. Jr. Gauch, and R.W. Zobel. 1990. Additive main effects and multiplicative interaction analysis of two international maize cultivar trials. Crop Sci. 30(3), 493-500. Doi: 10.2135/ cropsci1990.0011183X003000030003x

Dar, R.A. and J.P. Sharma. 2011. Genetic variability studies of yield and quality traits in tomato (Solanum lycopersicum L.). Int. J. Plant Breed. Genet. 5(2), 168-174. Doi: 10.3923/ijpbg.2011.168.174

Dumas, Y., M. Dadomo, G. Di Lucca, and P. Grolier. 2003. Effects of environmental factors and agricultural techniques on antioxidant content of tomatoes. J. Sci. Food Agric. 83(5), 369-382. Doi: 10.1002/jsfa.1370

Fanasca, S., G. Colla, G. Maiani, E. Venneria, Y. Rouphael, E. Azzini, and F. Saccardo. 2006. Changes in antioxidant 
content of tomato fruits in response to cultivar and nutrient solution composition. J. Agric. Food Chem. 54(12), 4319-4325. Doi: 10.1021/jf0602572

FAOSTAT. 2019. Value of agricultural production. In: http://www.fao.org/faostat/en/\#data/OV; consulted: November, 2019.

García, M., I. Escobar, and J. Berenguer. 2012. Flavoured tomatoes in soilless culture. Acta Hortic. 927, 481-487. Doi: 10.17660/ActaHortic.2012.927.61

Gest, N., H. Gautier, and R. Stevens. 2013. Ascorbate as seen through plant evolution: The rise of a successful molecule? J. Exp. Bot. 64(1), 33-53. Doi: 10.1093/jxb/ ers297

Havlin, J.L., J.D. Beaton, S.L. Tisdale, and W.L. Nelson. 2005. Soil fertility and fertilizers: An introduction to nutrient management. $7^{\text {th }}$ ed. Pearson Education, Franklin Lakes, NJ.

Hernández-Pérez, O.I., L.A. Valdez-Aguilar, I. Alia-Tejacal, A.D. Cartmill, and D.L. Cartmill. 2019. Tomato fruit yield, quality, and nutrient status in response to potassium: calcium balance and electrical conductivity in the nutrient solution. J. Soil Sci. Plant Nutr. 1-9. Doi: 10.1007/s42729-019-00133-9

Hortelano, R., H.E. Villaseñor, E. Martínez, M.F. Rodríguez, E. Espitia, and L.A. Mariscal. 2013. Estabilidad de variedades de trigo recomendadas para siembras de temporal en los Valles Altos de la Mesa Central. Rev. Mex. Cienc. Agríc. 4(5), 713-725. Doi: 10.29312/remexca. v4i5.1170

IPGRI, International Plant Genetic Resources Institute. 1996. Descriptores para el cultivo del tomate (Lycopersicon spp.). IPGRI, Rome.

Javaria, S., M.Q. Khan, and I. Bakhsh. 2012. Effect of potassium on chemical and sensory attributes of tomato fruit. J. Anim. Plant Sci. 22, 1081-1085.

Kanai, S., K. Ohkura, J.J. Adu-Gyamfi, P.K. Mohapatra, N.T. Nguyen, H. Saneoka, and K. Fujita 2007. Depression of sink activity precedes the inhibition of biomass production in tomato plants subjected to potassium deficiency stress. J. Exp. Bot. 58, 2917-2928. Doi: 10.1093/jxb/erm149

Kaur, H., S. Bedi, V.P. Sethi, and A.S. Dhatt. 2018: Effects of substrate hydroponic systems and different $\mathrm{N}$ and $\mathrm{K}$ ratios on yield and quality of tomato fruit. J. Plant Nutr. 41(12), 1547-1554. Doi: 10.1080/01904167.2018.1459689

Khan, A.A., M. Sajid, A. Rab, S. Alam, and A. Bari. 2014. Effect of potassium sources on the growth, yield and fruit quality of tomato cultivars. Sarhad J. Agric. 30(4), 442-450.

Leyva, R., C. Constán-Aguilar, B. Blasco, E. Sánchez-Rodríguez, L. Romero, T. Soriano, and J.M. Ruíz. 2013. Effects of climatic control on tomato yield and nutritional quality in Mediterranean screenhouse. J. Sci. Food Agric. 94(1), 63-70. Doi: 10.1002/jsfa.6191
Luna-Guevara, M. and A. Delgado-Alvarado. 2014. Importancia, contribución y estabilidad de antioxidantes en frutos y productos de tomate (Solanum lycopersicum L.). Avan. Inv. Agropec. 18(1), 51-66.

Machado, J., L.T. Braz, and G.V. Grilli. 2003. Desempenho de produção de cultivares de tomateiro tipo Cereja em diferentes espaçamentos. Hortic. Bras. 21(Supl. 2), 356-356.

Martí, R., M. Leiva-Brondo, I. Lahoz, C. Campillo, J. Cebolla-Cornejo, and S. Roselló. 2018. Polyphenol and 1 -ascorbic acid content in tomato as influenced by high lycopene genotypes and organic farming at different environments. Food Chem. 239, 148-156. Doi: 10.1016/j.foodchem.2017.06.102

Masheva, S. 2014. Recent trends of the breeding programs in main vegetables and potatoes in Bulgaria. J. Hort. 1, 1-3. Doi: 10.4172/2376-0354.1000e102

Nagata, M. and I. Yamashita. 1992. Simple method for simultaneous determination of chlorophyll and carotenoids in tomato fruit. J. Jpn. Soc. Food Sci. 39, 925-928. Doi: 10.3136/nskkk1962.39.925

Ozturk, B. and H. Ozer. 2019. Effects of grafting and green manure treatments on postharvest quality of tomatoes. J. Soil Sci. Plant Nutr. 19, 1-13. Doi: 10.1007/ s42729-019-00077-0

Panthee, D.R., C.X. Cao, S.J. Debenport, G.R. Rodriguez, J.A. Labate, L.D. Robertson, A.P. Breksa, E.V.D. Knaap, and B.B.M. Gardener. 2012. Magnitude of genotype $\mathrm{x}$ environment interactions affecting tomato fruit quality. HortScience 47(6), 721-726. Doi: 10.21273/ HORTSCI.47.6.721

Patel, K., A.I. Patel, D. Patel, and J.M. Vashi. 2017. Stability analysis for quality parameters in tomato (Solanum lycopersicum L.). Int. J. Chem. Stud. 5(3), 573-576.

Patil, R.B. 2011. Role of potassium humate on growth and yield of soybean and black gram. Int. J. Pharma Biosci. 2(1), 242-246.

Ramírez, S.L.F., S.F.R. Díaz, and E.J. Muro. 2012. Relation between soilless tomato quality and potassium concentration in nutritive solution. Acta Hortic. 947, 215222. Doi: 10.17660/ActaHortic.2012.947.26

Rebouças Neto, M.O., B.M. Azevedo, T.V.A. Viana, J.B.R. Mesquita, M.A.R. Carvalho, and L.C.C. Carvalho. 2016. Potassium fertilization via fertigation and conventional application on quality of tomato fruits. Rev. Bras. Eng. Agríc. Ambient. 20(10), 913-917. Doi: 10.1590/1807-1929/agriambi.v20n10p913-917

Rodriguez-Amaya, D.B. 2001. A guide to carotenoid analysis in foods. ILSI Human Nutrition Institute; One Thomas Circle, Washington, DC.

Rosales, M.A., L.M. Cervilla, J.J. Ríos, B. Blasco, E. Sánchez-Rodríguez, L. Romero, and J.M. Ruiz. 2009. Environmental conditions affect pectin solubilization in cherry tomato fruits grown in two experimental Mediterranean greenhouses. Environ. Exp. Bot. 67, 320327. Doi: 10.1016/j.envexpbot.2009.07.011 
Roselló, S., L. Galiana-Balaguer, and F. Nuez. 2000. Sources of high soluble solid and vitamin $\mathrm{C}$ content from Lycopersicon pimpinellifolium are interesting in breeding for internal quality of fresh market tomato. Tomato Genet. Coop. Rep. 50, 30-33.

Sánchez, A., E.F. Borrego, V.V. Zamora, C.J. Sánchez, and R.F. Castillo. 2015. Estimación de la interacción genotipo-ambiente en tomate (Solanum lycopersicum L.) con el modelo AMMI. Rev. Mex. Cienc. Agric. 6(4), 763778. Doi: 10.29312/remexca.v6i4.617

Savale, S.V. and A.I. Patel. 2017. Stability analysis for yield and quality attributes in tomato (Solanum lycopersicum L.). J. Pharmacogn. Phytochem. 6(6), 637-642.

Schwarz, D., G.B. Öztekin, Y. Tüzel, B. Brückner, and A. Krumbein. 2013. Rootstocks can enhance tomato growth and quality characteristics at low potassium supply. Sci Hortic. 149, 70-79. Doi: 10.1016/j. scienta.2012.06.013

Shahidi, F., A. Chandrasekara, and Y. Zhong. 2011. Bioactive phytochemicals in vegetables. pp. 125-158. In: Handbook of vegetables and vegetable processing. Vol. 1. Doi: $10.1002 / 9780470958346 . c h 6$

Spaldon, S., R.K. Samnotra, R. Dolkar, and D. Choudhary. 2017. Stability analysis and genotype $x$ environment interaction of quality traits in tomato (Solanum lycopersicum L.). Int. J. Curr. Microbiol. Appl. Sci. 6(2), 1506-1515. Doi: 10.20546/ijcmas.2017.602.168
Taber, H., P. Perkins-Veazie, S. Li, W. White, S. Rodermel, and Y. Xu. 2008. Enhancement of tomato fruit lycopene by potassium is cultivar dependent. HortScience 43(1), 159-165. Doi: 10.21273/HORTSCI.43.1.159

Tavallali, V., S. Esmaili, and S. Karimi. 2018. Nitrogen and potassium requirements of tomato plants for the optimization of fruit quality and antioxidative capacity during storage. J. Food Meas. Charact. 12(2), 755-762. Doi: 10.1007/s11694-017-9689-9

Wang, Y., R. Liu, S. Huang, and J. Jin. 2009. Effects of potassium application on flavor compounds of cherry tomato fruits. J. Plant Nutr. 32(9), 1451-1468. Doi: 10.1080/01904160903092663

Woldemariam, S.H., S. Lal, D.Z. Zelelew, and M.T. Solomon. 2018. Effect of potassium levels on productivity and fruit quality of tomato (Lycopersicon esculentum L.). J. Agric. Stud. 6(1), 104. Doi: 10.5296/jas.v6i1.12262

Wuzhong, N. 2002. Yield and quality of fruits of solanaceous crops as affected by potassium fertilization. Better Crops Int. 16(1), 6-8.

Zhao, X., Y. Liu, X. Liu, and J. Jian. 2018: Comparative transcriptome profiling of two tomato genotypes in response to potassium-deficiency stress. Int. J. Mol. Sci. 19(8), 2402. Doi: 10.3390/ijms19082402

Zörb, C., M. Senbayram, and E. Peiter. 2014. Potassium in agriculture - status and perspectives. J. Plant Physiol. 171(9), 656-669. Doi: 10.1016/j.jplph.2013.08.008 